\title{
Development of priming technology for enhanced planting value of seeds in kabuli chickpea (Cicer arietinum L.)
}

\section{Umesh Hiremath*}

Seed Science and Technology, National Seed Project (Crops), Seed Unit, University of Agricultural Sciences, Raichur (Karnataka), India

\section{Basave Gowda}

National Seed Project (Crops), Seed Unit, University of Agricultural Sciences, Raichur (Karnataka), India

\section{Lokesh G. Y.}

Department of Genetics and Plant Breeding, College of Agriculture, Raichur, University of Agricultural Sciences, Raichur (Karnataka), India

\section{B. S. Ganiger}

Department of Seed Science and Technology, College of Agriculture, B'Gudi, University of Agricultural Sciences, Raichur (Karnataka), India

${ }^{*}$ Corresponding author. Email: umesh3980@gmail.com

\section{Article Info}

https://doi.org/10.31018/ jans.v13i2.2507

Received: January 23, 2021

Revised: June 1, 2021

Accepted: June 8, 2021

\section{How to Cite}

Hiremath, U. et al. (2021). Development of priming technology for enhanced planting value of seeds in kabuli chickpea (Cicer arietinum L.). Journal of Applied and Natural Science, 13(2), 735 - 743. https://doi.org/10.31018/jans.v13i2.2507

\begin{abstract}
The continuous rise in global population demands more food production under limited land resources accompanied by climate change. More oversupply of quality seeds to meet ever-growing food demand is a highly challenging task. Seeds with low vigour level limit the growth and yield of crops at varied field conditions. Hence, an experiment was conducted to develop a technique for the fast and homogeneous growth of kabuli chickpea seeds. The priming treatments evaluated in the present study enhanced the various seed quality parameters of kabuli chickpea significantly when compared to control. Hydro-priming for 4 hours $\left(\right.$ at $20^{\circ} \mathrm{C}$ ) and air drying for 72 hours showed better results compared to rest of the treatments both in fresh seeds which recorded higher first count $(66.38 \%)$, germination $(92.50 \%)$ root length $(11.85 \mathrm{~cm})$, shoot length $(6.16)$, mean seedling length (18.01), dry seedling weight (747 mg), seedling vigour index-I (1665), higher speed of emergence (0.3992) and old seeds with higher first count $(61.88 \%)$, germination $(74.13 \%)$ root length $(8.15 \mathrm{~cm})$, shoot length $(5.85 \mathrm{~cm})$, mean seedling length $(14.00$ $\mathrm{cm})$, seedling dry weight $(611 \mathrm{mg})$, seedling vigour index-I (1056), higher speed of emergence (0.3814). The aged seeds have recorded $29 \%$ increase in germination percentage in contrast to 8 percent increases in fresh seeds. Kabuli chickpea seeds could be subjected to hydropriming, an affordable, alternative, and eco-friendly technique for improving seed and seedling vigour of kabuli chickpea.
\end{abstract}

Keywords: Hydropriming, Kabuli chickpea, Planting value, seed vigour, Speed of emergence

\section{INTRODUCTION}

Chickpea (Cicer arietinum L.), commonly called gram, bengal gram, or garbanzo bean, is the most vital food grain legume cultivated in South Asia. It is also one of the first grain crops cultivated by man and has been uncovered in Middle Eastern archaeological sites dated to the eighth millennium BC (Zohary and Hopf, 2000). Two diverse market types, desi and kabuli, prevail in chickpea (Pundir et al., 1985). The desi types cover about $85 \%$ of chickpea area with common characteristics like small, angular shaped, dark-colored seeds with a rough surface, pink flowers, anthocyanin pigmentation on the stems, and either semi-erect or semispreading growth habit and the remaining $15 \%$ area is covered by kabuli type, wherein we find large rams head shaped smooth surface seeds, lack of anthocyanin pigmentation, and semi-spreading growth habit (Ahmad et al., 2005).

Global yields of chickpea are low (700-800 kg ha-1), and have been fairly stagnant for the last two decades. Various biotic and abiotic factors hinder the realization of chickpea yield potential. The lower production and productivity trend of chickpea in India can be attributed 
to: (i) the shift in crop area from favourable to marginal environments; (ii) the slow varietal replacement rate and other production technologies; and (iii) chickpea cultivation in poor soils under inconsistent rainfall conditions (Parthasarathy et al., 2010). Apart from these constraints, the establishment of kabuli chickpea under these resource-poor dryland conditions is problematic. The above-mentioned problems impart a serious threat to kabuli chickpea cultivation. Hence, it necessitates developing the appropriate technology to improve seed viability and vigour. Seed priming is one of the potential techniques for enhancing the seed and seedling performance, starting from uniform and faster seed germination, early seedling establishment, better final stand establishment that enables the initial germination process, and restricting the final phase of seed germination i.e., radicle emergence (Umesha et al., 2014).

In recent years, several approaches are being employed in order to induce abiotic stress tolerance in plants. Seed priming is an effective, practical and facile technique to enhance rapid and uniform emergence, high seedling vigour, and better yields in many field crops, particularly under unfavourable environmental conditions (Paparella et al., 2015). The word priming was given by Heydecker in 1973 for the soaking drying seed treatments. Theophrastus (372-287 BC) had proposed presoaking of cucumber seeds in milk or water to enable them to germinate earlier and vigorously (Michael Evanari, 1984). Heydecker (1973) effectively practiced seed priming to enhance germination and seedling emergence under various stress conditions. The seed priming treatments trigger metabolic processes activated during the phase II of germination, which are then temporally stopped before a loss of desiccation occurs (Paparella et al., 2015).

Various researchers reported the beneficial effects of seed priming treatments to improve seeds vigour and viability under a wide range of environment. Seed priming with various agents including organic and inorganic substituents, bioagents, phytohormones have been found superior for improving seed performance. (Umesha et al., 2014). The overall consequence of seed priming comprises augmented seed vigour defined as the whole set of properties conditioning seed lots performance in an extensive range of environments (Zhang et al., 2015). The studies related to the development of seed priming technology in kabuli chickpea are very meagre. Keeping in view, the present investigation was undertaken to identify suitable priming treatments for fresh and aged seeds to improve their seed viability, vigour and seed quality.

\section{MATERIALS AND METHODS}

The experiment was conducted at the National Seed Project (Crops), Seed Unit, University of Agricultural
Sciences, Raichur, Karnataka, India during 2018 and 2019. The seed material of kabuli chickpea variety MNK-1 with two vigour levels (Fresh seeds: Lot 1, One year old seeds: Lot 2) was collected from Seed Unit, UAS, Raichur and used for the experiment. These low and high vigour seeds were subjected to priming with different treatments mentioned in table 1 . The microbial consortia were procured from ICAR-Indian Institute of Seed Science, Mau, India (Accession numbers awaited).

Method/dosage of treatment of microbial consortia $100 \mathrm{ml}$ of liquid formulation BioNPK, Biogrow, Biophos, Drought Alleviating Bacteria (containing $1 \times 10^{9} \mathrm{cfu}$ ) was diluted in $1000 \mathrm{ml}$ water. To this diluted suspension, 10 grams of sucrose was added. The final suspension was sprinkled over the seeds (two hours before sowing). Then the seeds were mixed with hands and kept for 45 minutes, shade dried and sown.

Both fresh and aged seeds were used to conduct viability and vigour tests. Each test was conducted in a completely randomized design. The moisture content of seed before and after seed priming was determined by the oven dry method as per the ISTA Rules

Table 1. Details of priming treatments used in the experiment.

$\mathrm{T}_{1}$ - Control (Untreated)

$\mathrm{T}_{2}$ - Thiram seed treatment @ 2g/Kg

$\mathrm{T}_{3}$ - Hydropriming - Soaking in water for $4 \mathrm{~h}\left(\right.$ at $\left.20^{\circ} \mathrm{C}\right)$ and air-drying at $25^{\circ} \mathrm{C}$ for $48 \mathrm{~h}$

$\mathrm{T}_{4}$ - Halopriming- Soaking in $\mathrm{KNO}_{3}(@ 0.3 \%)$ solution and drying

$\mathrm{T}_{5}$ - Halopriming- Soaking in $\mathrm{MgNO}_{3}(@ 2 \%)$ solution and drying

$\mathrm{T}_{6}$ Halopriming- Soaking in $\mathrm{KH}_{2} \mathrm{PO}_{4}(@ 0.5 \%)$ solution and drying

$\mathrm{T}_{7}$ - Halopriming- Soaking in $\mathrm{ZnSO}_{4}(@ 0.3 \%)$ solution

$\mathrm{T}_{8}$ - Halopriming- Soaking in $\mathrm{MnSO}_{4}$ (@0.5\%) solution

$\mathrm{T}_{9}$ - Halopriming- Soaking in $\mathrm{ZnSO}_{4}(@ 0.3 \%)+\mathrm{MnSO} 4$ (@0.5\%) solution for and drying

$\mathrm{T}_{10}$ - Seed coating (on hydro primed seeds) with Trichoderma harzianum (CFU - 2X106er gm) @ $15 \mathrm{~g} / \mathrm{kg}$ seed $(15 \mathrm{~g}$ in $50 \mathrm{ml}$ of water and applied on $1 \mathrm{~kg}$ of seed uniformly. Later seeds were shade dried for $20-30$

$\mathrm{T}_{11}$ - Seed coating (on hydro primed seeds) with Trichoderma viride (CFU - 2 X $10^{9}$ per gm) @ $10 \mathrm{~g} / \mathrm{kg}$ seed

$\mathrm{T}_{12}$ - Seed coating (on hydro primed seeds) with BioNPK

$\mathrm{T}_{13}$ - Seed coating (on hydro primed seeds) with Biogrow

$\mathrm{T}_{14}$ - Seed coating (on hydro primed seeds) with Biophos

$T_{15}$ - Seed coating (on hydro primed seeds)) with Drought Alleviating Bacteria + BioNPK

$\mathrm{T}_{16}$ - Seed coating (on hydro primed seeds) with Drought

$\mathrm{T}_{17}$ - Seed coating (on hydro primed seeds) with Drought Alleviating Bacteria + Biophos 
(Anonymous, 2010). The number of normal seedlings germinated on the 5th day was counted and expressed in percentage for the first count. The standard germination test was done as per the ISTA rules using between paper method (Anonymus, 2010). Ten normal seedlings from each of the replications from the germination test were carefully removed at the end of the test day and used for measuring root length, shoot length and mean seedling length and expressed in centimetre. The seedlings used for recording seedling length were kept in a hot air oven at $80^{\circ} \mathrm{C}$ for 48 hours. The dry weight was recorded and expressed as mean seedling dry weight in milligrams per 10 seedlings. Seedling vigour index-I and II was calculated as per the procedure of Abdul-Baki and Anderson (1973). The incidence of seed-borne pathogens (\%) was studied by the blotter paper method (TP) as per ISTA procedures (Anonymus, 2010). Twenty-five seeds from each replication were positioned equidistantly in sterile glass petridishes of $15 \mathrm{~cm}$ diameter containing 2 moist blotter paper (Whatman No. 1). Then the petridishes were incubated at $20^{\circ} \mathrm{C}$ for seven days with 12 hours light and 12 hours dark cycles. After incubation, seeds were evaluated under sterio-binocular microscope for the presence of infection. The infected seeds are counted and expressed as percentage of total infection.

The number of seeds that had germinated on each day from the beginning of germination experiment was counted and speed of emergence was calculated as per the procedure of Ellis and Roberts (1981). The data collected from the experiment were analyzed statistically by the procedure prescribed by Sundarrajan et al. (1972). The absolute control treatment was compared with the rest of the treatment by following ANOVA: Two factor statistical analysis.

\section{RESULTS AND DISCUSSION}

\section{Effect of seed priming on first count and seed ger- mination}

The results revealed that various priming treatments enhanced the germination and other seed quality parameters of fresh and aged seeds. The hydroprimed fresh seeds exhibited significantly higher percentage of normal seedlings in first count $(66.38 \%)$, germination percentage $(92.50 \%)$ followed by Halopriming- soaking in $\mathrm{KH}_{2} \mathrm{PO}_{4}(@ 0.5 \%)$ solution and drying $(64.38 \%$, $88.75 \%$, respectively) as compared to un-primed seeds $(56.00 \%, 85.75 \%$, respectively). There was a significant increase (at $1 \%$ level of significance) in normal seedlings at first count, percent germination in case of aged seed lot which undergone priming with water $(61.88 \%, 74.13 \%$ respectively) as compared to un-primed seeds (Table 2). These results agree with Saad and Azhar (2020) who demonstrated the signifi- cant effect of seed priming on first count (\%) in mung bean, which is an important parameter of seed vigour. Hydro-priming is a simple and low cost-effective priming technology that does not involve any specific apparatus as it involves the use of distilled water as a priming medium. Fujikura et al. (1993) presented hydropriming as a simple and inexpensive method of seed priming. The characteristic features of primed seeds are augmented germination rate, better uniformity in germination, and in some cases higher seed germination percent (Basra et al., 2005), enhanced germination under unfavorable conditions (Lin and Sung, 2001). Improved germination rate and uniformity have been ascribed to metabolic repair during first phase of seed germination i.e., imbibition (Bray et al., 1989), accumulation of germination augmenting metabolites (Basra et al., 2005), osmotic modification (Bradford, 1986), and, for seeds that are not subjected to drying back to original moisture content after treatment, a simple reduction in imbibition lag time (Bradford, 1986). The aged seeds performed better regarding increasing germination per cent compared to fresh seeds because seeds intact with all quality characteristics, obviously the prospect of enhancing seed quality, are restricted compared to seeds of lower quality with physiological deficiencies (Umesha et al., 2014).

In the present investigation, it was observed that percent improvement in seed quality due to seed priming in old lot (aged seeds) is more as compared to fresh lot (Table 2). Umesha et al., (2016) opined that seed deterioration can be rectified to the extent possible by the technique of seed priming. Their study of biochemical investigations on vigour enhancement in aged seeds upon seed priming in onion clearly indicated that priming would reestablish the lost seed vigour in aged seeds due to reactivation of enzyme activity in old seeds. The germination percentage improved from $60 \%$ to $79.5 \%$ and $72.5 \%$ in $\mathrm{GA}_{3}$ and hydroprimed, respectively. Priming also restored the lost seed vigour in aged seeds due to recurrence of proteins and increased enzyme activity in old seeds and the appearance of these proteins in priming treatments are related to priming persuaded proteins in contrast to their absence in the aged seeds, which are essential for germination and longevity of seeds. The shift in the enzyme activities upon priming indicates that the mobilization of storage material may be accountable for improved germination and vigour in primed seeds than unprimed aged seeds.

\section{Effect of seed priming on seedling length and seedling dry weight}

Seed quality in particular seed viability and vigor can have a significant impact on the crop establishment and the yield of a crop. Healthy plants with appropriate 


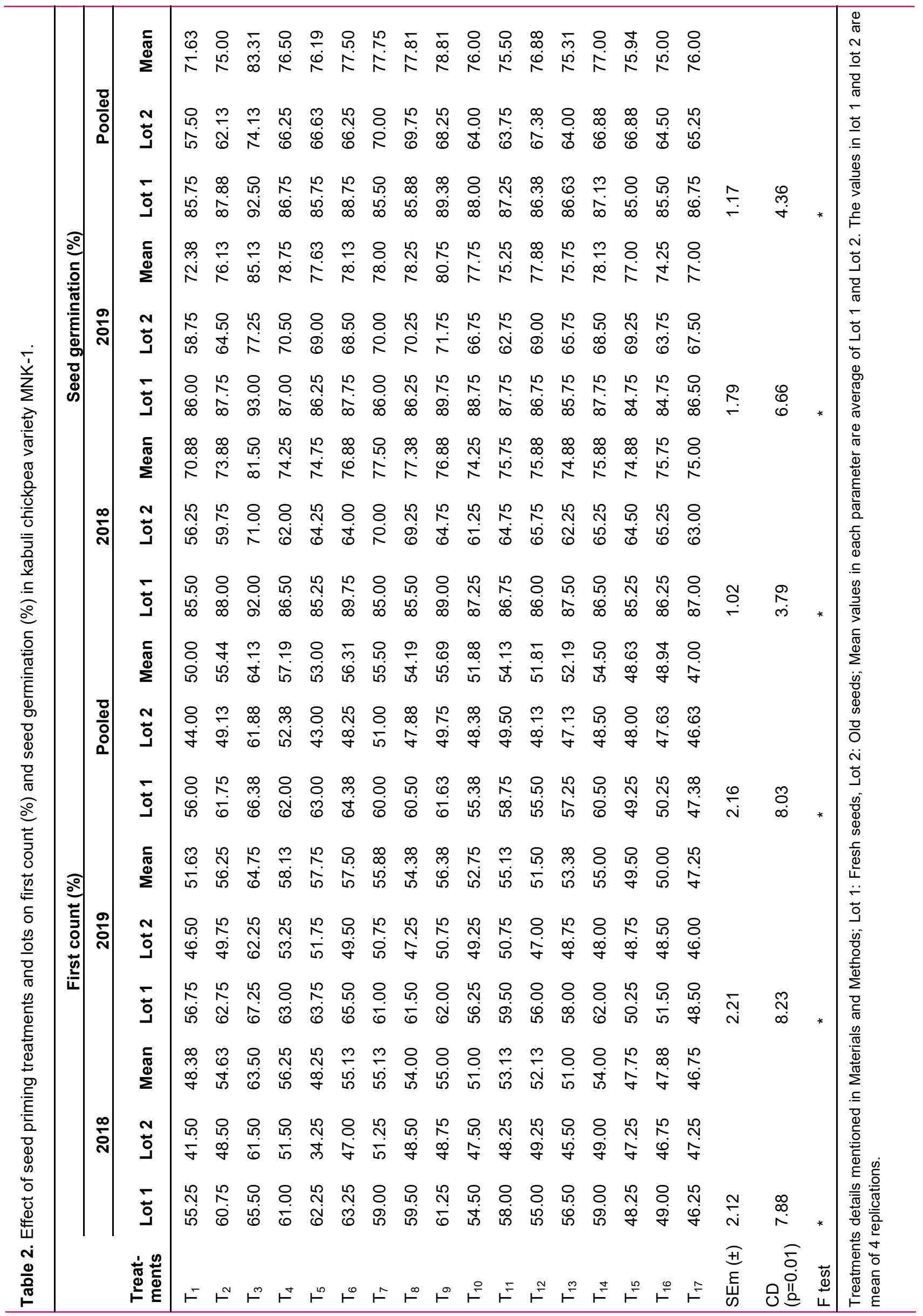


root systems can better survive even under unfavourable conditions and early vigorous seedling establishment has been associated with higher yields (Harris et al., 2000). Significant variations in root length, shoot length, mean seedling length, mean seedling dry weight were noticed among the seed lots and priming treatments. Among seed lots, higher root length (9.84 $\mathrm{cm})$, shoot length $(5.19 \mathrm{~cm})$ mean seedling length $(15.05 \mathrm{~cm})$, seedling dry weight $(671 \mathrm{mg})$ was registered in fresh seeds and it was lower in old seeds $(11.15 \mathrm{~cm}, 4.45 \mathrm{~cm}, 11.15 \mathrm{~cm}$ and $575 \mathrm{mg}$ respectively). Among the priming treatments, hydroprimed fresh seeds recorded highest root length $(11.85 \mathrm{~cm})$, shoot length $(6.16 \mathrm{~cm})$ mean seedling length $(18.01 \mathrm{~cm})$, seedling dry weight $(747 \mathrm{mg})$ whereas, old seeds subjected to hydropriming exhibited higher seedling vigour parameters $(8.15 \mathrm{~cm}, 5.85 \mathrm{~cm}, 14.00 \mathrm{~cm}$ and $611 \mathrm{mg}$ respectively) (Fig. 1 to Fig. 4). The findings of the study are in agreement with, Shantha Nagarajan and Panditha (2001) who also observed that hydropriming of tomato seeds lead to enhanced germination, speed of germination and seedling dry weight of aged seeds to a smaller extent as compared to osmopriming. Surekha (2002) also described that hydration dehydration treatment had a positive impact on seed quality in onion

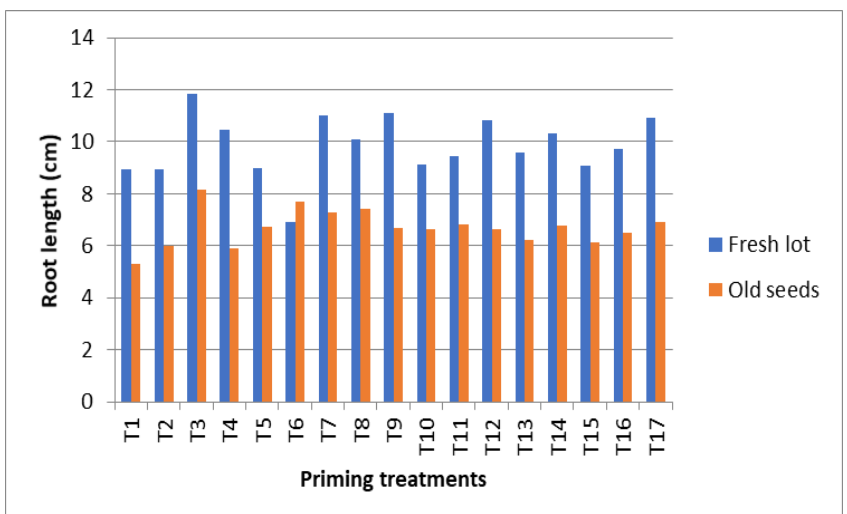

Fig. 1. Effect of seed priming treatments and lots on root length (cm) in kabuli chickpea variety MNK-1.

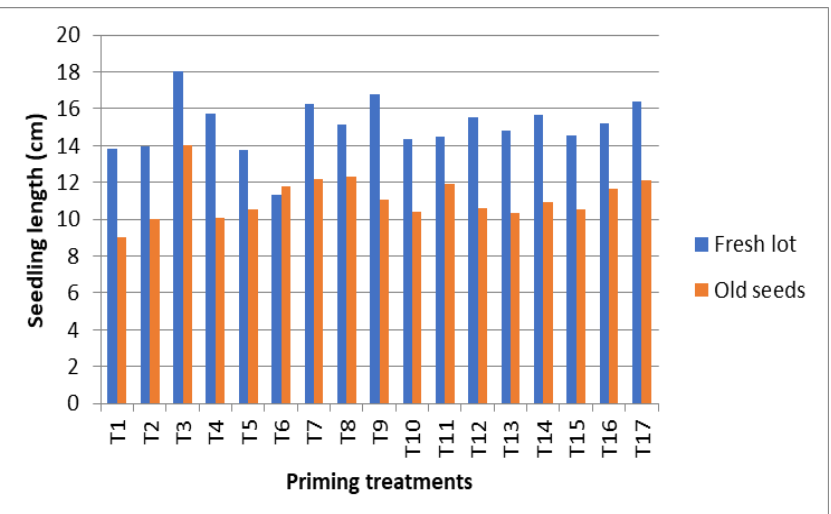

Fig. 3. Effect of seed priming treatments and lots on mean seedling length $(\mathrm{cm})$ in kabuli chickpea variety MNK-1. cultivars. Vigorous seedling growth manifested through the greater seedling length and seedling dry weight is essential for better plant establishment, plant growth and ultimately higher yield. Shaila et al., (2019) opined that bitter gourd seeds subjected to hydropriming enhanced the seed germination, accelerated the seedling growth through higher shoot length, ultimately increase the yield.

\section{Effect of seed priming on seedling vigour indices}

Seed priming in kabuli chickpea showed a positive correlation between germination, seedling vigour index. The fresh seeds hydroprimed exhibited higher seedling vigour index (SVI-I and II) (1665, 69095 respectively) than other priming treatments. Old seeds that undergone priming with water (1038, 45258 respectively) recorded highest seedling vigour index-I and II due to increased seedling length and seedling dry weight by seed priming (Table 3 ). The results comply with Umesha et al. (2014), who also opined that priming of onion seeds with different chemicals resulted in an increased length of seedlings. The seedling vigour index of fresh seeds was significantly higher than the aged seeds. The increase in seedling length by priming treatments can be due to the beneficial effect in uniform

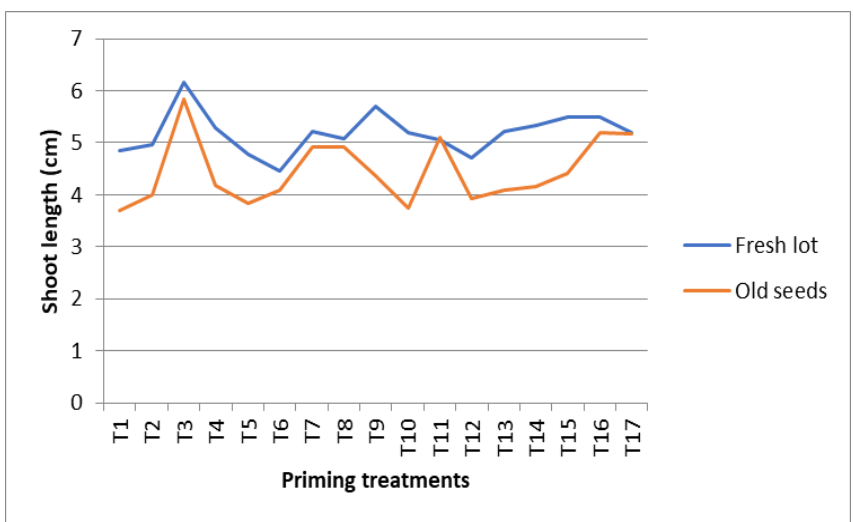

Fig. 2. Effect of seed priming treatments and lots on shoot length $(\mathrm{cm})$ in kabuli chickpea variety MNK-1.

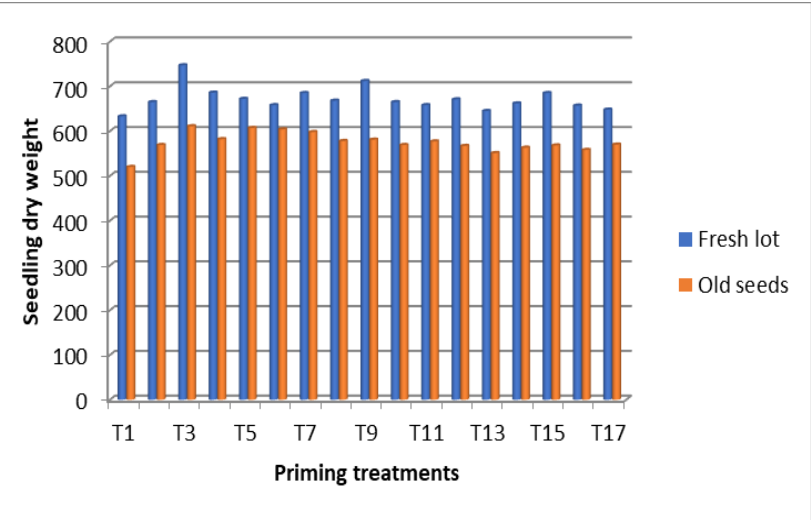

Fig. 4. Effect of seed priming treatments and lots on seedling dry weight $(\mathrm{mg})$ in kabuli chickpea variety MNK-1. 
Hiremath, U. et al. / J. Appl. \& Nat. Sci. 13(2), 735 - 743 (2021)

Table 4. Effect of seed priming treatments and lots on speed of emergence in kabuli chickpea variety MNK-1.

\begin{tabular}{|c|c|c|c|c|c|c|c|c|c|}
\hline \multirow[b]{3}{*}{ Treatments } & \multicolumn{6}{|c|}{ Speed of emergence } & \multirow{2}{*}{\multicolumn{3}{|c|}{ Pooled }} \\
\hline & \multicolumn{3}{|c|}{2018} & \multicolumn{3}{|c|}{2019} & & & \\
\hline & Lot 1 & Lot 2 & Mean & Lot 1 & Lot 2 & Mean & Lot 1 & Lot 2 & Mean \\
\hline $\mathrm{T}_{1}$ & 0.326 & 0.276 & 0.301 & 0.298 & 0.290 & 0.294 & 0.3169 & 0.3064 & 0.3116 \\
\hline $\mathrm{T}_{2}$ & 0.339 & 0.292 & 0.315 & 0.281 & 0.270 & 0.275 & 0.3066 & 0.3139 & 0.3102 \\
\hline$T_{3}$ & 0.394 & 0.379 & 0.387 & 0.387 & 0.364 & 0.375 & 0.3992 & 0.3814 & 0.3903 \\
\hline $\mathrm{T}_{4}$ & 0.259 & 0.303 & 0.281 & 0.287 & 0.277 & 0.282 & 0.2588 & 0.2871 & 0.2729 \\
\hline$T_{5}$ & 0.328 & 0.327 & 0.328 & 0.313 & 0.296 & 0.305 & 0.3304 & 0.3104 & 0.3204 \\
\hline $\mathrm{T}_{6}$ & 0.335 & 0.328 & 0.332 & 0.307 & 0.292 & 0.299 & 0.3224 & 0.3194 & 0.3209 \\
\hline $\mathrm{T}_{7}$ & 0.317 & 0.353 & 0.335 & 0.316 & 0.303 & 0.310 & 0.3229 & 0.3099 & 0.3164 \\
\hline $\mathrm{T}_{8}$ & 0.299 & 0.298 & 0.299 & 0.316 & 0.357 & 0.337 & 0.3008 & 0.3146 & 0.3077 \\
\hline$T_{9}$ & 0.359 & 0.307 & 0.333 & 0.383 & 0.343 & 0.363 & 0.3982 & 0.3443 & 0.3713 \\
\hline$T_{10}$ & 0.346 & 0.286 & 0.316 & 0.279 & 0.273 & 0.276 & 0.3182 & 0.3065 & 0.3124 \\
\hline$T_{11}$ & 0.338 & 0.333 & 0.336 & 0.298 & 0.275 & 0.287 & 0.3141 & 0.3225 & 0.3183 \\
\hline$T_{12}$ & 0.334 & 0.292 & 0.313 & 0.289 & 0.260 & 0.275 & 0.3117 & 0.3116 & 0.3117 \\
\hline$T_{13}$ & 0.353 & 0.346 & 0.349 & 0.303 & 0.295 & 0.299 & 0.3127 & 0.3436 & 0.3282 \\
\hline$T_{14}$ & 0.358 & 0.344 & 0.351 & 0.294 & 0.278 & 0.286 & 0.3123 & 0.3395 & 0.3259 \\
\hline$T_{15}$ & 0.320 & 0.320 & 0.320 & 0.283 & 0.261 & 0.272 & 0.3015 & 0.3018 & 0.3016 \\
\hline$T_{16}$ & 0.333 & 0.308 & 0.321 & 0.307 & 0.292 & 0.299 & 0.2997 & 0.3408 & 0.3202 \\
\hline$T_{17}$ & 0.324 & 0.325 & 0.324 & 0.317 & 0.280 & 0.299 & 0.3041 & 0.3368 & 0.3205 \\
\hline $\operatorname{SEm}( \pm)$ & 0.011 & & & 0.02 & & & 0.010 & & \\
\hline $\mathrm{CD}(\mathrm{p}=0.01)$ & 0.031 & & & - & & & - & & \\
\hline$F$ test & * & & & NS & & & NS & & \\
\hline
\end{tabular}

Treatments details mentioned in Materials and Methods; Lot 1: Fresh seeds, Lot 2: Old seeds; Mean values in each parameter are average of Lot 1 and Lot 2 . The values in lot 1 and lot 2 are mean of 4 replications.

germination, due to intensified hydrolytic process and better uptake of moisture. Nascimento et al. (2004) reported that priming increased the germination of seed of low vigour and response was cultivar dependent. Avila et al., (2008) evaluated the effect of hydration (distilled water) and pre-osmotic treatments $(-1.5 \mathrm{MPa}$ of osmotic potential in manitol solution for four periods of treatment $\left(12,24,48\right.$ and 72 hours) at $\left.10^{\circ} \mathrm{C}\right)$ on the quality of high and low vigour canola seeds. They opined that pre-osmotic conditioning with manitol solution was not efficient in improving the germination and vigour of the rape seeds. However, hydro-priming was a suitable priming technique in canola seeds and was effective in the low vigour lot. Christos et al., (2019) opined that hydropriming faba bean seeds produced more vigorous seedlings than non-primed seeds in seedling vigor index.

\section{Effect of seed priming on seed infection}

All the priming treatments improved the seed quality parameters when compared to control. Among the various priming treatments, hydroprimed seeds and seeds treated with thiram @ 2g/Kg recorded less infection in both fresh seeds $(1.75 \%)$ compared to unprimed seeds $(6.13 \%)$ and other treatments. In the case of old seeds, seeds treated with thiram @ $2 \mathrm{~g} / \mathrm{Kg}$ and hydroprimed seeds recorded less infection $(2.50,2.63 \%$, respectively) compared to un-primed seeds. The lesser infection in thiram treated seeds is due to the wellknown effect of fungicidal activity on fungal organisms.

\section{Effect of seed priming on speed of emergence}

Faster and uniform emergence of seedlings in the field is very critical in ensuring better crop growth and yield in any crop. In addition, the period between sowing and plant establishment is important in the production cycle of a crop. Therefore, it would be desirable to reduce the period between sowing and seedling emergence and to decrease the time between the emergences of the first and last seedlings (Heydecker et al., 1973). The less time gap between the emergence of the first and last seedling would reduce the competition with seeds and increases both uniformity at plant maturity and yield. High seedling vigour at an early stage of the crop yields 
good returns to farmers. Studies conducted by several workers showed the beneficial effects of seed priming on speed, synchronization and uniformity of germination, often leading to improved stand establishment. In the present investigation, primed seeds germinated faster as compared to unprimed seeds, as evident from the higher speed of emergence in hydroprimed seeds both in fresh and aged seeds $(0.3992,0.3814$ respectively) compared to un-primed seeds $(0.3169,0.3064$ respectively) (Table 4). During seed priming, the hydration process enables the most primitive physiological stages of germination to complete at the earliest time and perhaps physiological repair of membranes and organelles affected during seed storage ensuing in more speedy and uniform seedling emergence (Copeland and Mc Donald, 1995). Casenave and Toselli (2007) demonstrated that hydropriming increased the speed of germination significantly, compared to control seeds, reduced the thermal time required for radicles to emerge and improved seed vigour in cotton. Hydropriming is a very simple, economical and environmentally friendly type of seed priming (Jamil et al., 2016). Several studies have established that hydropriming enhanced germination of various crop species resulting in higher values of germination, root growth, shoot growth and seedling vigour index. Shaila et al. (2019) opined that hydropriming of bitter gourd seeds enhanced seed germination, seedling growth and other growth parameters. Christos et al. (2019) found that the hydro-priming of faba bean seeds enhanced the germination speed by $16.2 \%$, germination synchrony by $20.7 \%$, and seedling vigor index $13.4 \%$, but did not affect significantly final germination percentage and mean daily germination compared with non-primed seeds. Our study shows that seedlings from primed seeds emerge faster and produce more vigorous seedlings, as it is evident from higher values of speed of emergence, seedling vigour indices in hydroprimed seeds than from non-primed seeds. As evidenced by higher seedling growth parameters in this experiment due to seed priming, the increased seed vigour was similar to the findings of Shaila et al. (2019) in bittergourd.

\section{Conclusion}

The priming treatments evaluated in the present study enhanced the seed quality parameters of kabuli chickpea significantly when compared to control. Hydro priming for 4 hours (at $20^{\circ} \mathrm{C}$ ) and air drying for 72 hours showed better results than the rest of the fresh and old seeds treatments. The fresh seeds hydroprimed exhibited significantly (at $1 \%$ level of significance) higher percentage of normal seedlings in the first count (66.38 $\%$ ), germination percentage $(92.50 \%)$, followed by Halopriming- soaking in $\mathrm{KH}_{2} \mathrm{PO}_{4}(@ 0.5 \%)$ solution and drying $(64.38,88.75 \%$ respectively) as compared to un -primed seeds $(56.00,85.75 \%$ respectively). There was a significant increase in normal seedlings at first count, percent germination in the aged seed lot, which had undergone priming with water $(61.88,74.13 \%$ respectively) compared to un-primed seeds. The present data further indicates that the aged seeds have recorded 29 per cent increase in germination percentage in contrast to 8 per cent increase in fresh seeds. Kabuli chickpea seeds could be hydro-primed as a pre-sowing seed enhancement technique, a cost-effective, affordable alternative for improving germination and seed vigour.

\section{Conflict of interest}

The authors declare that they have no conflict of interest.

\section{REFERENCES}

1. Abdul-Baki, A.A. \& Anderson, J.D. (1973). Vigour determination in soybean seed by multiple criteria. Crop Science, 13(3), 630-633.

2. Ahmad, F., Gaur, P.M. \& Croser, J.S. (2005). Chickpea (Cicer arietinum L.) In: Genetic Resources, Chromosome Engineering and Crop Improvement. Taylor \& Francis, London, UK, pp. 229-267.

3. Anonymous. (2010). International rules for seed testing, Zurich, Switzerland.

4. Ávila, M.R., Braccini, A.L., Scapim, C.A., Albrecht, L.P., Rodovalho, M. \& Fracaro, M. (2008). Hydration and preosmotic treatments on canola rape seeds (Brassica napus L.). Seed Science and Technology, 36, 218-224.

5. Basra, S.M.A., Farooq, M. \& Tabassum, R. (2005). Physiological and biochemical aspects of seed vigor enhancement treatments in fine rice (Oryza sativa L.). Seed Science and Technology, 33, 25-29.

6. Bradford, K, J. (1986). Manipulation of seed water relations via osmotic priming to improve germination under stress conditions. Hort. Sci., 21, 1105-1112.

7. Bray, C.M., Davison, P.A., Ashraf, M. \& Taylor, R.M. (1989). Biochemical changes during osmopriming of leek seeds. Annals of Botany, 63, 185-193.

8. Casenave, E.C. \& Toselli, M.E. (2007). Hydropriming as a pre-treatment for cotton germination under thermal and water stress conditions. Seed Science and Technology, 35, 88-89.

9. Christos A. D., Spyridon D. K. \& Sideris, F. (2019). Hydropriming effects on seed germination and field performance of faba bean in spring sowing. Agriculture, 9, 201. doi:10.3390/agriculture9090201.

10. Copeland, L.O. \& M.C. Donald, M.B. (1995). Principles of seed science and technology $3^{\text {rd }}$ edition., Chapman and Hall, New York.

11. Ellis, R.H. \& Roberts, E.H. (1981). The quantification of ageing and survival in orthodox seeds. Seed Science and Technology, 9, 373-409.

12. Fujikura, Y., Kraakh, L.A., Basra, S. \& Karssen, C.M. (1993). Hydropriming, a simple and inexpensive priming method. Seed Science and Technology, 21, 411-415. 
13. Harris, D., Tripathi, R.S. \& Joshi A. (2000). On- farm priming to improve crop establishment and yield in directseeded rice p.164 in IRRI: International Workshop on Dry -seeded Rice Technology, Bangkok, 25 - 28 January 2000. The international Rice Research institute, Manila, Philippines.

14. Heydecker, W.J., Heydecker, J., Higgins. \& Gulliver, K. (1973). Accelerated germination by osmotic seed treatment. Nature, 246, 42-46.

15. Jamil, E., Zeb, S. Ali, Q. S. Ahmad, N. Sajis, M. Siddique, S. \& Saleem, S.M. (2016). Effect of seed soaking on seed germination and growth of bitter gourd cultivars. Pure and Applied Biology, 5(1), 31-36. https://doi.org/10.19045/ bspab.2016.50005.

16. Lin, J.M. \& Sung, J.M. (2001). Pre-sowing treatment for improving emergence of bittergourd seedling under optimal and sub-optimal temperatures. Seed Science and Technology, 29, 39-50.

17. Michael Evanari. (1984). Seed Physiology: Its History from antiquity to the beginning of the $20^{\text {th }}$ century. Bot. Rev, 50 , 119-142.

18. Nascimento, W.M. \& Arago, F.S. (2004). Muskmelon seed priming in relation seed vigour. Scientia Agri., 61, 114-117.

19. Parthasarathy Rao P., Birthal P.S., Bhagavatula, S. \& Bantilan, M.C.S. (2010). Chickpea and Pigeonpea Economies in Asia: Facts, Trends and Outlook, Patancheru, Andhra Pradesh, India: International Crops Research Institute for the Semi-Arid Tropics, pp 76.

20. Paparella, S., Araújo, S. S., Rossi, G., Wijayasinghe, M., Carbonera, D. \& Balestrazzi, A. (2015). Seed riming: state of the art and new perspectives. Plant Cell Rep. 34, 12811293. doi:10.1007/s00299-015-1784-y.

21. Pundir, R.P.S., Rao, N.K. \& Van der Maesen, L.J.G (1985). Distribution of qualitative traits in the world germplasm of chickpea (Cicer arietinum L.). Euphytica, 34, 697-703.

22. Saad, J.K. Al-Salhy \& Azhar A. Rasheed (2020). Effect of mung bean seed priming methods and duration on seed germination and seedling vigour. Plant Arch., 20(1), 27-31.
23. Shaila Shermin Tania, Md, Mokter Hossain, M. \& Abul Hossain (2019). Effects of hydropriming on seed germination, seedling growth and yield of bitter gourd. Journal of Bangladesh Agricultural University, 17(3), 281287.

24. Shantha Nagarajan \& Pandita, V.K. (2001). Improvement in germination characteristics in artificially aged seeds of tomato by osmoconditioning. Seed Res, 29(2), 136-140.

25. Sundarrajan, N., Nagaraju, S., Venkataramana, S. \& Jaganatha, M.H. (1972). Design and analysis of experiments. University of Agricultural Sciences, Hebbal, Bangalore.

26. Surekha, M. (2002). Studies on the influence of seed invigouration treatments on seed quality and storability in onion (Allium cepa L.). M. Sc. (Agri.) Thesis, University of Agricultural Sciences, Bangalore.

27. Umesha., Vasudevan, S.N., Bhanuprakash, K., Shakuntala, N.M. \& Arvindkumar, P.R. (2014) Standardization of suitable chemicals, methodology and vigour enhancement through seed priming technique in onion seeds. Green Farming, 5 (2), 177-181.

28. Umesha., Vasudevan, S.N., Bhanuprakash, K., Manjunatha, B., Sarika, G. \& Amruta, N. (2016). Biochemical investigations on vigour enhancement in aged seeds upon seed priming in onion. Journal of Applied and Natural Science, 8 (2), $855-859$.

29. Zhang, F., Yu, J., Johnston, C.R., Wang, Y., Zhu, K., Lu, F., Zhang, Z. and Zou, J. (2015). Seed priming with polyethylene glycol induces physiological changes in sorghum (Sorghum bicolor L. Moench) seedlings under suboptimal soil moisture environments. PLoS One, 0: e0140620. DOI: 10.1371/ journal.pone. 0140620 .

30. Zohary, D. \& Hopf, M. (2000). Pulses. In domestication of plants in the old world: The origin and spread of cultivated plants in West Asia, Europe, and the Nile Valley, $3^{\text {rd }}$ Edition, Oxford University Press, New York, pp 108. 